\title{
Pelatihan Pemanfaatan Limbah Plastik Menjadi Berbagai Kreasi Daur Ulang Bagi Masyarakat Desa Penyak
}

\author{
Yuant Tiandho' $^{1)}$, Herman Aldila' ${ }^{2)}$, Yekti Widyaningrum ${ }^{3)}$, Tri Kusmita ${ }^{4)}$, Anisa Indriawati' ${ }^{5)}$ \\ Widodo B. Kurniawan ${ }^{6}$, Fitri Afriani ${ }^{7)}$
}

Jurusan Fisika, Fakultas Teknik, Universitas Bangka Belitung ${ }^{1,2,3,4,5,6,7)}$

Jl. Kampus Peradaban, Bangka, Kep. Bangka Belitung, Indonesia

Email:yuant@ubb.ac.id

\begin{abstract}
ABSTRAK
Sebagai daerah kepulauan, penanganan limbah plastik di Provinsi Kepulauan Bangka Belitung merupakan aspek yang perlu ditangani secara serius. Selain karena berfokus pada pengembangan daerah wisata, limbah plastik akan mudah terbawa hingga ke laut dan rawan terdegradasi menjadi mikroplastik yang kerap dikonsumsi oleh hewan laut. Kegiatan pengabdian kepada masyarakat ini berfokus di Desa Penyak, Kec. Koba, Kab. Bangka Tengah, Provinsi Kepulauan Bangka Belitung. Untuk mengatasi permasalahan plastik yang ada di lokasi tersebut, maka dilakukan pelatihan kepada masyarakat terutama untuk anggota Pendidikan Kesejahteraan Keluarga (PKK) terkait pemanfaatan limbah plastik menjadi berbagai kreasi daur ulang seperti tas, kotak pensil, dan berbagai rupa souvenir. Progam pelatihan dilakukan melalui pemberian materi dan pelatihan secara langsung sehingga dapat meningkatkan pemahaman dan keterampilan para peserta pelatihan. Agar wawasan masyarakat menjadi semakin luas maka pelatihan dilakukan bersama dengan start-up Ecoplantstic yang berfokus pada pengembangan produk berbasis limbah. Melalui evaluasi diketahui bahwa pelatihan yang diberikan dapat meningkatkan pengetahuan dan keterampilan masyarakat dalam melakukan pengolahan limbah plastik menjadi berbagai kreasi daur ulang dan terdapat beberapa peserta yang berencana untuk mengembangkan keterampilan yang diperoleh untuk keperluan wirausaha.
\end{abstract}

Kata kunci: daur ulang, kepulauan, pengolahan limbah plastik

ABSTRACT

As an archipelago, handling plastic waste in the Province of Bangka Belitung Islands is an aspect that needs to be taken seriously. Apart from being focused on developing tourist areas, plastic waste will easily be carried to the sea and prone to be degraded into microplastics, often consumed by marine animals. This community service activity focuses on Penyak Village, Kec. Koba, Kab. Central Bangka, Bangka Belitung Islands. To solve the plastic problem in that location, the community service team conducted training for the community, especially for Pendidikan Kesejahteraan Keluarga (PKK) members, related to processing plastic waste into various recycled creations such as bags, pencil cases, and different kinds of souvenirs. The training program is carried out by providing materials and direct training to increase the understanding and skills. To broaden people's insights, the team conducted training with the Ecoplantstic start-up, which focuses on developing waste-based products. Through the evaluation, it is known that the training provided can improve the knowledge and skills of the community in processing plastic waste into various recycled creations, and several participants plan to develop the skills acquired for entrepreneurial purposes.

Keywords: recycling, archipelago, plastic waste treatment 


\section{Pendahuluan}

Desa Penyak adalah salah satu desa yang terletak di Kecamatan Koba, Kabupaten Bangka Tengah. Desa Penyak memiliki luas wilayah sekitar $75 \mathrm{~km}^{2}$ dengan total jumlah penduduk berkisar 3.589 jiwa. Mayoritas mata pencaharian masyarakat di desa ini adalah nelayan dan petani. Secara lokasi, Desa Penyak merupakan desa yang berbatasan langsung dengan pantai Laut Cina Selatan (Afriani, Widyaningrum, Kurniawan, Aldila, \& Tiandho, 2020). Pada Gambar 1(a) disajikan lokasi Desa Penyak (ditunjukkan oleh garis merah) yang tampak jelas bahwa desa ini memiliki garis pantai yang cukup panjang. Adapun pada Gambar 1(b) disajikan foto salah satu pantai yang terletak di Desa Penyak yang bernama Pantai Buluh Perindu. Selain itu, Desa Penyak memiliki bukit yang berbatasan dengan pantai sehingga memiliki panorama yang indah. Oleh karena itu, Pemerintah Desa Penyak berencana melakukan pengembangan daerah wisata di desa ini secara intensif. Hal tersebut sesuai dengan program unggulan Pemerintah Provinsi Kepulauan Bangka Belitung yang mengharapkan agar sektor pariwisata dapat terus berkembang di provinsi ini (Sandi, Nurdandi, \& Tiandho, 2019; Gusa, Sari, Afriani, Sunanda, \& Tiandho, 2020).

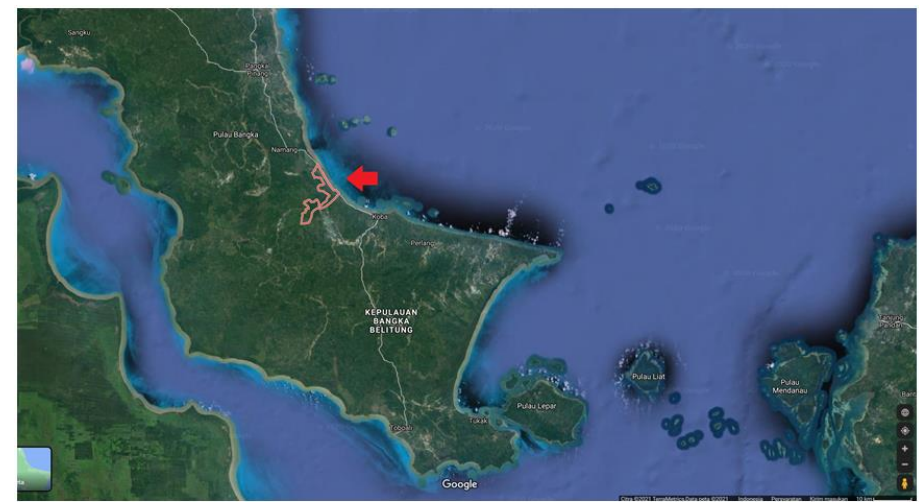

(a)

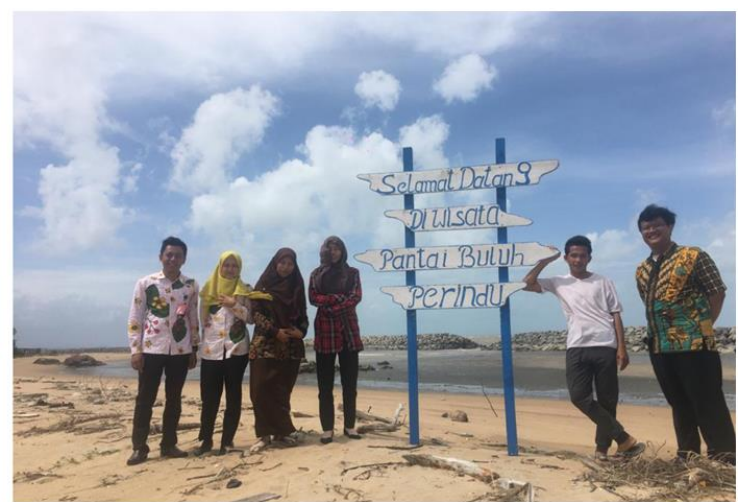

(b)

Gambar 1. (a) Lokasi Desa Penyak (ditunjukkan oleh panah merah); (b) Pantai Buluh Perindu di Desa Penyak

Berdasarkan diskusi dengan Pemerintah Desa Penyak diketahui bahwa pada saat ini Desa Penyak mengalami permasalahan terkait penanggulangan sampah. Karena terletak tepat di tepi pantai maka sampah akan mudah terbawa ke laut dan dapat mencemari laut. Dikhawatirkan plastik akan terdegradasi menjadi mikroplastik yang kerap dikonsumsi oleh hewan laut (Sujithira \& Velmurugan, 2020). Terlebih jika wisata di Desa Penyak mengalami pengembangan maka tentu saja volume sampah di desa ini mengalami peningkatan dan dapat mengurangi keindahan daerah wisata di desa ini.

Pada dasarnya, Pemerintah Desa Penyak melalui Badan Usaha Milik Desa (BUMDes) pada tahun 2019 telah berinisiatif untuk membangun suatu instalasi pengelolaan sampah yang disebut sebagai Bank Sampah Desa Penyak. Bank Sampah Desa Penyak terletak di lahan milik desa yang relatif jauh dari pemukiman seperti ditunjukkan oleh Gambar 2. Instalasi pengelolaan sampah ini dibangun dengan tujuan untuk mengolah berbagai sampah mulai dari organik yaitu menjadi kompos/pupuk serta pengolahan ulang sampah plastik. Namun demikian, Pemerintah Desa Penyak mengharapkan agar sampah-sampah tersebut, terutama sampah anorganik dapat diolah kembali menjadi suatu kreasi buah tangan yang memilki nilai ekonomi lebih besar dibandingkan sekedar dijual ulang dalam bentuk plastik cacah. Hal ini juga bertujuan agar Desa Penyak memiliki suatu ikon souvenir yang kelak dapat diperkenalkan seiring dengan pengembangan potensi wisata di desa ini. 


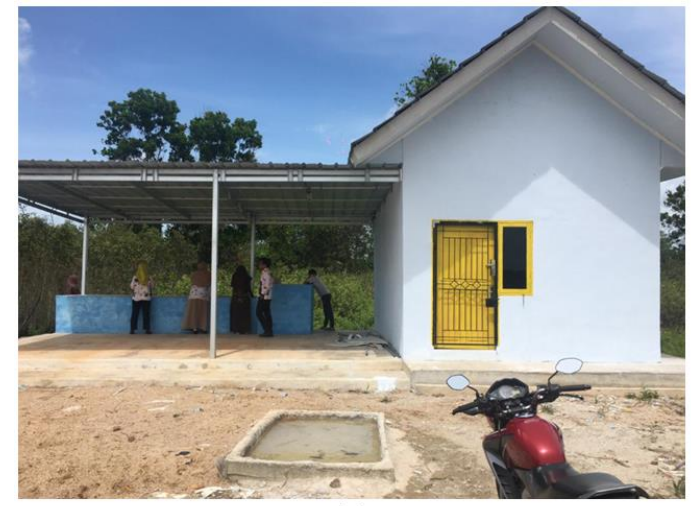

(a)

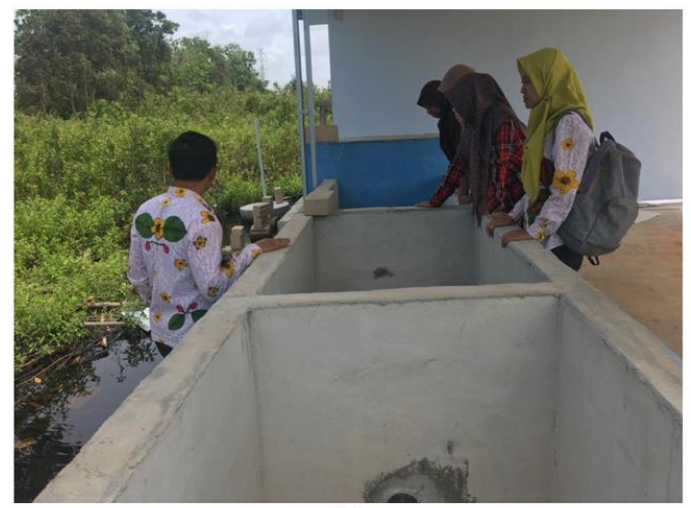

(b)

Gambar 2. (a) Lokasi Bank Sampah Desa Penyak dan (b) tempat pencucian sampah plastik

Oleh karena itu, sebagai solusi untuk mengatasi permasalahan yang muncul maka pada program pengabdian kepada masyarakat ini dilakukan pelatihan terkait pemanfaatan limbah plastik menjadi berbagai kreasi daur ulang kepada masyarakat di Desa Penyak. Hal ini bertujuan agar masyarakat dapat memiliki keterampilan dan wawasan yang lebih luas terkait dengan pemanfaatan limbah plastik. Selain itu, diharapkan melalui pelatihan ini masyarakat dapat menghasilkan produkproduk yang kelak dapat menjadi ikon tambahan seiring dengan pengembangan Desa Penyak sebagai daerah wisata.

\section{Tinjauan Pustaka}

Dalam beberapa tahun terakhir, isu penanggulangan limbah plastik merupakan isu yang hangat dikaji di berbagai negara. Karena berbagai keunggulannya, plastik telah mendominasi berbagai produk kemasan menggantikan kemasan kaleng dan gelas. Plastik memiliki sifat yang kuat, tahan terhadap air, tidak mengalami korosi, dan ringan (Nasution, 2015). Namun, dibalik keunggulannya tersebut plastik bersifat sulit diurai di alam. Sampah plastik dapat bertahan hingga puluhan bahkan ribuan tahun sebelum terurai secara sempurna (Chamas, et al., 2020). Terlebih ketika limbah plastik terbawa hingga ke wilayah perairan seperti sungai dan laut. Ketika plastik terdegradasi menjadi potongan-potongan kecil yang lazim disebut sebagai mikroplastik maka banyak organisme menganggap mikroplastik sebagai makanan. Dampaknya, telah banyak terjadi kasus keracunan plastik pada hewan di wilayah perairan serta terdapatnya potongan plastik pada tubuh berbagai seafood. Apabila seafood terkontaminasi mikroplastik tersebut dikonsumsi oleh manusia maka tentu akan dapat mengganggu kesehatan (Smith, Love, Rochman, \& Neff, 2018). Oleh karena itu, sebagai daerah kepulauan, pengolahan dan pengelolaan limbah plastik di Kepulauan Bangka Belitung sudah selayaknya mendapat perhatian khusus.

Saat ini terdapat berbagai metode pengolahan limbah plastik seperti untuk keperluan menjadi material paving blok (Setyawan, Putro, Santosa, \& Fajar, 2020), bahan bakar alternatif (Prihatmoyo, Dermawan, \& \& Bisono, 2018), dan produk kreasi daur ulang (Nadlifatin, 2018). Salah satu produk kreasi daur ulang yang dapat dikembangkan dari limbah plastik diantaranya adalah berbagai rupa tas (Nadlifatin, 2018; Arico \& Jayanthi, 2017). Pemanfaatan limbah plastik menjadi produk kreasi daur ulang merupakan pemanfaatan yang menjanjikan bagi masyarakat. Selain memperoleh keuntungan dari perilaku meminimalisir pembuangan limbah plastik ke lingkungan, produk kreasi daur ulang berbasis limbah plastik memiliki nilai ekonomis yang baik. Hal ini dikarenakan pemanfaatan limbah plastik sebagai produk kreasi daur ulang relatif sederhana dan memiliki tampilan yang indah apabila dikerjakan dengan sungguh-sungguh (Kanti, Mukhirah, \& Dewi, 2020). Namun, meskipun telah diketahui bahwa pemanfaatan limbah plastik memiliki nilai ekonomis yang baik, tidak semua orang tertarik mendalami bisnis ini. Agar bisnis produk berbasis limbah plastik dapat berjalan dengan baik dibutuhkan suatu sistem pengelolaan sampah mulai dari 
pengumpulan sampah, kerja sama dengan para pengepul sampah, adanya fasilitas pengolahan sampah hingga telah memahami pangsa pasar dari produk berbasis limbah plastik yang dihasilkan. Oleh karena itu, seringkali masyarakat membutuhkan suatu pelatihan terlebih dahulu agar dapat mengenal bisnis produk kreatif berbasis limbah plastik (Putra \& Yurindala, 2010).

\section{Metodologi Penelitian}

Kegiatan pengabdian bagi masyarakat yang akan dilakukan di Desa Penyak, Kecamatan Koba, Kabupaten Bangka Tengah terdiri dari tiga tahapan yang meliputi: tahap persiapan, tahap pelaksanaan, dan tahap evaluasi. Adapun sasaran dari kegiatan ini adalah para anggota PKK yang ada di Desa Penyak. Pemilihan sasaran kegiatan tersebut dikarenakan para ibu yang terlibat dalam keanggotaan PKK mayoritas adalah para ibu rumah tangga.

\subsection{Tahap Persiapan}

Pada tahap persiapan dimulai dengan rapat koordinasi tim meliputi pengarahan dan pembagian penanggung jawab program kerja. Melalui rapat koordinasi awal ini, masing-masing pelaksana kegiatan pengabdian memiliki gambaran umum tentang hal-hal teknis yang perlu dilakukan saat kegiatan pengabdian. Kemudian dilanjutkan dengan survei lapangan di Desa Penyak untuk memastikan kesesuaian kegiatan pengabdian masyarakat dengan kondisi wilayah. Selain disamping melakukan penyesuaian, pada kegiatan ini juga akan dilakukan koordinasi dengan pihak desa. Sehingga kerja sama serta penyelarasan program dengan pihak desa dapat berjalan dengan baik. Agar masyarakat memperoleh gambaran pengelolaan limbah yang semakin jelas maka dalam kegiatan pengabdian kepada masyarakat ini akan dilaksanakan bersama dengan start-up Ecoplantstic. Oleh karena itu, pada tahapan persiapan tim juga berkoordinasi dengan Ecoplantstic terkait dengan produk-produk nyata yang dapat dihasilkan dari limbah rumah tangga.

\subsection{Tahap Pelaksanaan}

Tahap pelaksanaan diawali dengan proses pembelian serta pemesanan alat dan bahan yang akan digunakan dalam kegiatan pengabdian kepada masyarakat terutama terkait kebutuhan pelatihan. Setelah itu juga disusun materi/bahan untuk kegiatan pengabdian kepada masyarakat yang terkait dengan berbagai produk aneka kreasi daur ulang sampah.

Pelaksanaan kegiatan pengabdian kepada masyarakat diselenggarakan bersama dengan perangkat desa dan anggota PKK. Adapun kegiatan tersebut dilaksanakan di Kantor Desa Penyak. Secara umum, kegiatan pengabdian yang akan dilaksanakan berupa kegiatan pelatihan terkait dengan pelatihan pengolahan sampah plastik menjadi berbagai kreasi daur ulang bagi masyarakat Desa Penyak. Masyarakat akan diberikan materi melalui metode ceramah dan diskusi selanjutnya masyarakat juga akan diberikan pelatihan secara langsung terkait pembuatan beberapa produk kreasi berbasis limbah plastik.

\subsection{Evaluasi}

Kegiatan pengabdian ini akan dievaluasi untuk menentukan kesuksesan kegiatan pengabdian kepada masyarakat setelah diadakan kegiatan ini. Proses evaluai yang akan dilakukan berupa pengecekan peningkatan pengetahuan serta potensi pengembangan pengolahan limbah plastik pada tingkat rumah tangga. Evaluasi tersebut dilakukan melalui pemberian kuisioner sebelum dan setelah pelaksanaan kegiatan pengabdian kepada masyarakat.

\section{Hasil dan Pembahasan}

Kegiatan koordinasi dengan mitra Desa Penyak telah dilaksanakan pada bulan Agustus 2020 dan dihadiri langsung oleh Kepala Desa Penyak beserta para stafnya. Melalui kegiatan koordinasi ini Kepala Desa Penyak menyatakan bahwa dirinya merasa senang karena kegiatan yang diajukan mendapat respon positif dari Universitas Bangka Belitung. Selain itu, Kepala Desa Penyak juga 
menyatakan bersedia dan siap untuk mengundang masyarakatnya agar mengikuti pelatihan yang akan diberikan pada pelatihan ini namun tetap dengan mematuhi protokol kesehatan Covid-19 sehingga jumlah peserta yang diizinkan tidak melebihi kapasitas ruang pertemuan desa berdasarkan peraturan selama pandemi Covid-19.

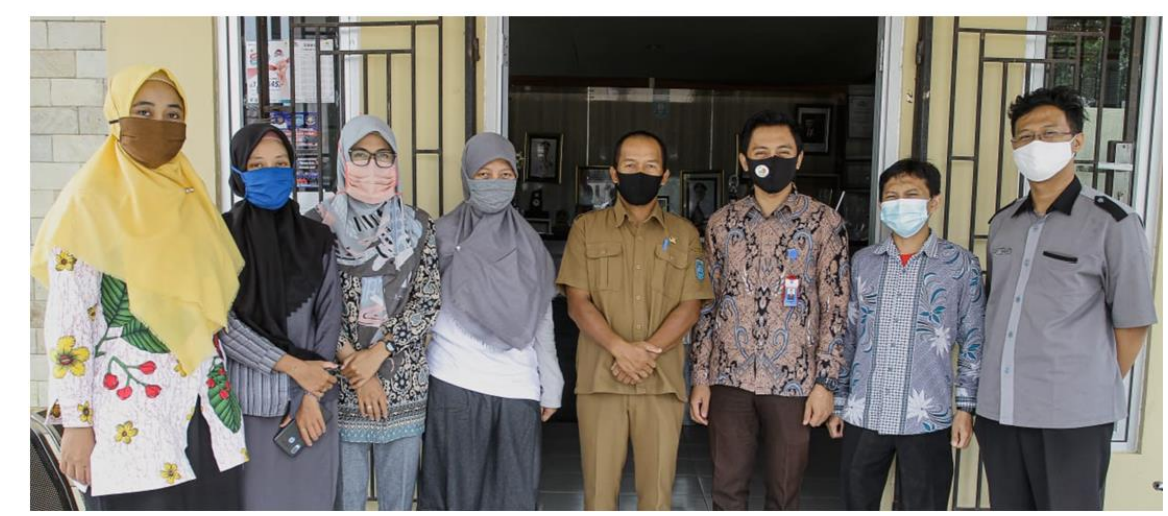

Gambar 3. Foto bersama dengan Kepala Desa Penyak

Selain melibatkan dosen, kegiatan pengabdian kepada masyarakat ini juga melibatkan peran mahasiswa yang tergabung dalam start-up Ecoplantstic agar kegiatan tri dharma yang dilaksanakan dapat memberikan dampak yang lebih besar. Start-up Ecoplantstic merupakan suatu start-up yang berfokus pada pengembangan produk-produk yang ramah lingkungan atau produk berbasis limbah. Oleh karena itu, agar tim pengabdian memiliki persamaan persepsi dan memiliki kemampuan yang baik ketika melaksanakan pelatihan kepada masyarakat maka dilakukan pelatihan kepada tim yang terlibat. Setelah dilakukan kegiatan pelatihan tersebut maka tim yang terlibah memiliki pengetahuan dan keterampilan yang baik terkati pembuatan berbagai produk kreasi berbasis limbah plastik. Pelatihan dilakukan berkaitan dengan jenis-jenis pemanfaatan sampah seperti ditunjukkan pada Gambar 4.

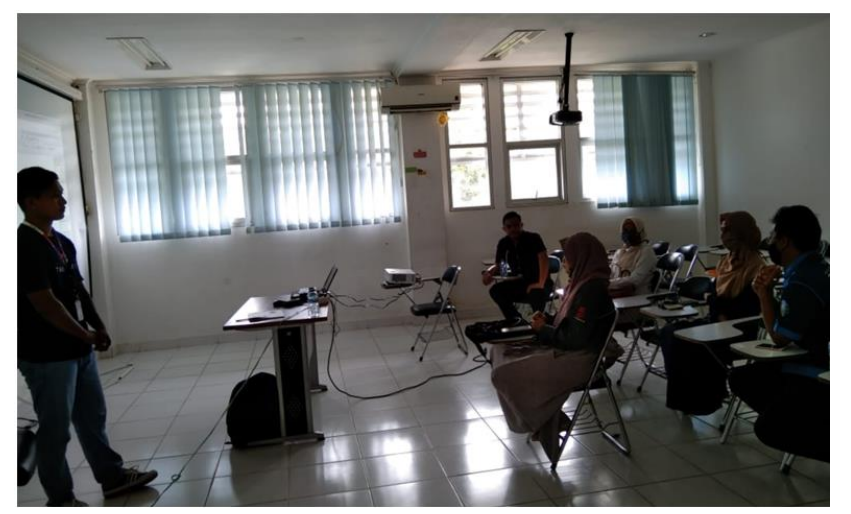

Gambar 4. Pelatihan dengan mahasiswa yang tergabung dalam start-up Ecoplantstic

Kegiatan pelatihan pengabdian kepada masyarakat di Desa Penyak diselenggarakan pada bulan November 2020 di Kantor Desa Penyak, Kecamatan Koba, Kabupaten Bangka Tengah. Kegiatan pelatihan diikuti oleh masyarakat Desa Penyak terutama oleh ibu-ibu yang tergabung dalam PKK Desa Penyak. Adapun peserta pelatihan terdiri dari 17 orang. Kegiatan pelatihan dimulai dengan pre-test yang bertujuan untuk menggali informasi terkait dengan jumlah sampah plastik yang dihasilkan oleh masing-masing rumah tangga, tingkat pemanfaatan sampah tersebut, hingga pengetahuan terkait pemanfaatan sampah plastik sebagai bahan dasar produk kreatif. Pada Gambar 5 disajikan hasil pre-test yang telah dilakukan. Melalui hasil pre-test terkait dengan jumlah plastik 
yang dihasilkan oleh suatu rumah tangga di Desa Penyak diketahui bahwa sekitar $6 \%$ responden menyatakan bahwa mereka membuang sampah plastik lebih dari 20 kemasan tiap minggunya. Selain itu, secara berturut-turut, sekitar $24 \%$ dan $41 \%$ reseponden menghasilkan sampah plastik sebanyak 10 sampai dengan 15 kemasan dan 15 sampai dengan 20 kemasan tiap minggunya. Adapun sisa dari keseluruhan responden yaitu 29\% menyatakan bahwa mereka menghasilkan limbah sampah plastik yang relatif kecil yaitu kurang dari 10 kemasan per minggunya.

Pada Gambar 5(b) diketahui bahwa masyarakat Desa Penyak mayoritas telah memanfaatkan sebagian plastik kemasan. Namun berdasarkan diskusi lebih lanjut diketahui bahwa pemanfaatan yang dilakukan masih relatif sangat sederhana seperti penggunaan kembali plastik kresek untuk keperluan pengemasan atau penyimpanan. Pemanfaatan yang dilakukan belum dilakukan secara kreatif sehingga cenderung tidak memiliki nilai tambah. Hasil ini sesuai dengan hasil pre-test pada Gambar 5(c) yang menyatakan bahwa masih banyak masyarakat yang belum mengetahui pemanfaatan sampah plastik sebagai bahan kreatif (sebanyak 59\%).

Setelah dilakukan pre-test kegiatan pelatihan dilanjutkan dengan pemberian materi terkait dengan pengelolaan limbah plastik pada tingkat rumah tangga. Berbagai macam jenis kreasi daur ulang plastik beserta metode pembuatannya dipresentasikan untuk memberikan gambaran pengolahan limbah plastik kepada para peserta. Beberapa produk kreasi daur ulang yag dipaparkan diantaranya adalah: tas plastik, kotak pensil, serta pembuatan kertas daur ulang yang berasal dari limbah sabut kelapa. Kegiatan pemberian materi ini ditunjukkan oleh Gambar 6.

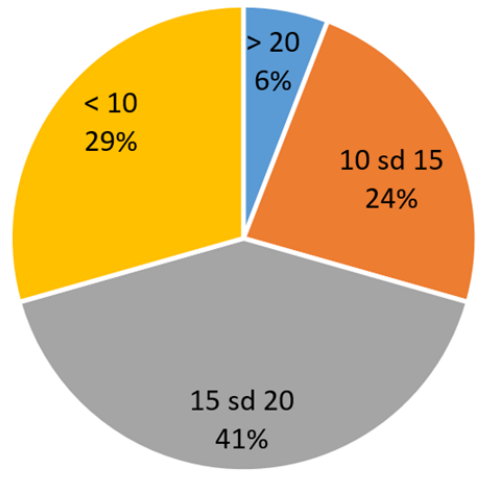

(a)

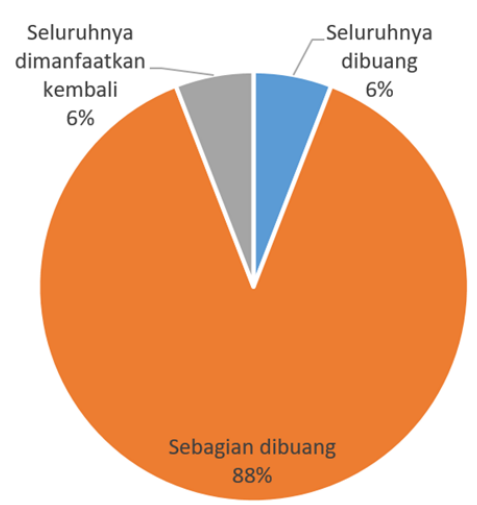

(b)

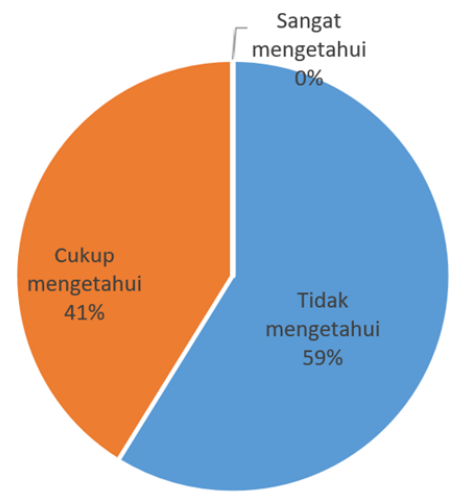

(c)

Gambar 5. Hasil pre-test kegiatan pelatihan: (a) jumlah sampah plastik yang dihasilkan dalam seminggu tiap rumah tangga (jumlah dalam satuan kemasan); (b) pemanfaatan sampah plastik; (c) tingkat pengetahuan pemanfaatan sampah plastik sebagai bahan dasar produk kreatif 


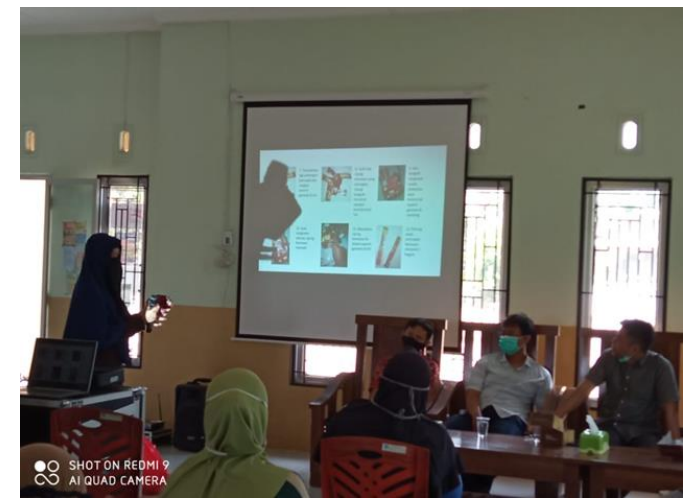

Gambar 6. Pemberian materi terkait pemanfaatan limbah plastik menjadi produk kreatif kepada para peserta pelatihan

Selain memberikan materi terkait dengan pemanfaatan limbah plastik menjadi produk kreatif, tim pelaksana pengabdian kepada masyarakat juga memberikan pendampingan praktik secara langsung. Hal ini bertujuan agar para peserta pelatihan tidak hanya memiliki pengetahuan terkait dengan pengolahan limbah plastik menjadi berbagai produk kreatif melainkan juga memiliki keterampilan yang baik. Dengan memanfaatakan limbah plastik, para peserta secara langsung dibimbing untuk membuat produk-produk kreatif seperti tas, kotak pensil, dan berbagai souvenir lain. Ketika diberikan pelatihan tersebut para peserta tampak antusias. Seluruh peserta pelatihan mengikuti petunjuk dari tim pengabdian dengan baik ketika membuat berbagai produk kreatif seperti ditunjukkan pada Gambar 7(a) dan (b). Setelah proses pelatihan selesai dan para peserta telah dapat membuat berbagai produk kreatif berbasis limbah dilakukan foto bersama seperti ditunjukkan oleh Gambar 7(c).

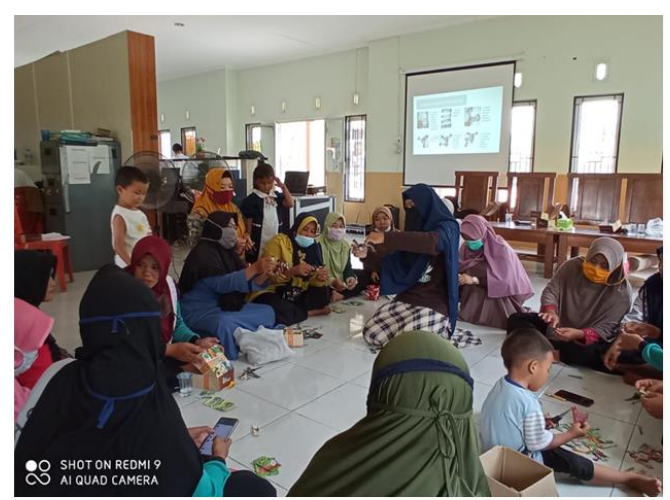

(a)

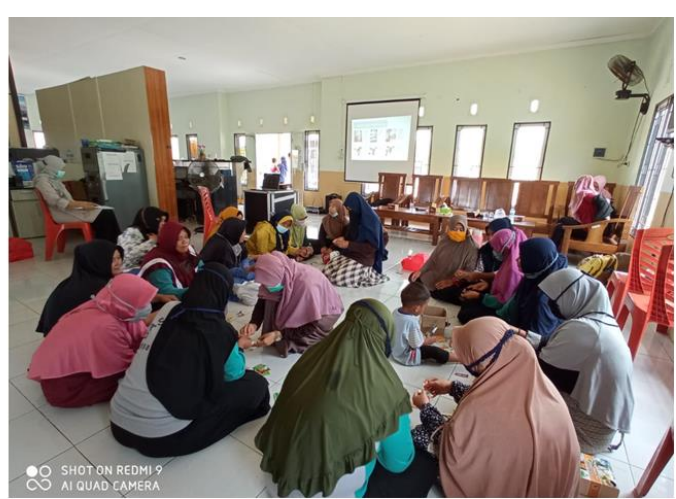

(b)

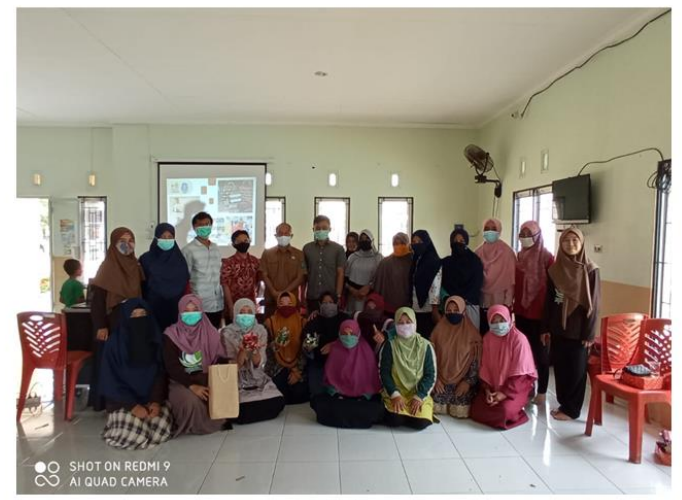

(c)

Gambar 7. (a) dan (b) kegiatan pelatihan kepada para peserta dan (c) foto bersama tim pengabdian dengan para peserta 
Untuk mengetahui efektivitas kegiatan pelatihan maka dilakukan evaluasi terkait dengan peningkatan pemahaman dan kemungkinan akan menerapkan keterampilan mengolah limbah plastik untuk keperluan komersil. Evaluasi dilakukan melalui kuisioner yang diisi oleh peserta kegiatan pelatihan seperti ditunjukkan oleh Gambar 8.

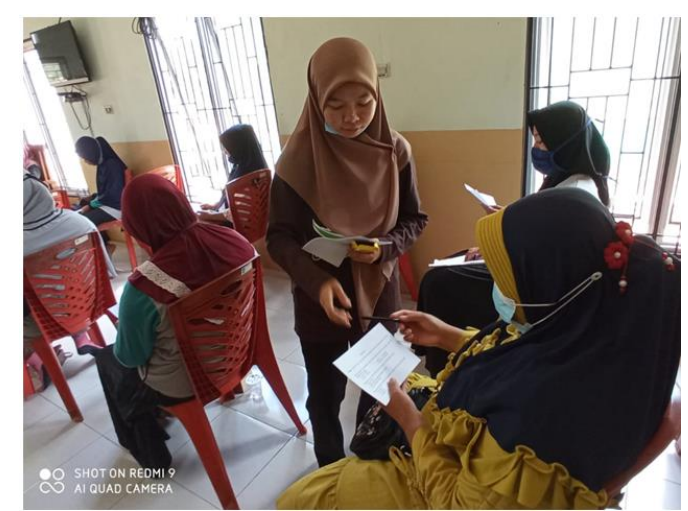

Gambar 8. Evaluasi kegiatan pengabdian yang telah dilakukan

Pada Gambar 9 disajikan hasil evaluasi dari kegiatan pengabdian yang dilakukan. Tampak bahwa pada 9(b) terjadi peningkatan pemahaman para peserta pelatihan terkait dengan pemanfaatan sampah plastik sebagai bahan dasar produk kreatif. Sebanyak $82 \%$ peserta kegiatan menyatakan telah sangat mengetahui, sebanyak $18 \%$ cukup mengetahui, dan tidak ada lagi peserta yang tidak mengetahui. Oleh karena itu dapat dinyatakan bahwa kegiatan pelatihan baik melalui pemberian materi maupun pelatihan secara langsung dapat meningkatkan pemahaman para peserta secara signifikan. Sebanyak $65 \%$ peserta pelatihan menyatakan bahwa mereka akan menerapkan keterampilan yang diperoleh untuk mengolah limbah plastik menjadi produk kreatif. Namun, masih terdapat $18 \%$ responden yang ragu-ragu dan $17 \%$ yang merasa kesulitan untuk menerapkannya. Berdasarkan distribusi pada Gambar 9(c) diketahui bahwa mayoritas peserta akan menerapkan keterampilan tersebut untuk keperluan sendiri (rumah tangga). Terdapat $41 \%$ peserta yang berkeingian untuk dapat mengaplikasikan keterampilan tersebut untuk berwirausaha. Berdasarkan diskusi lebih lanjut, diketahui bahwa beberapa masyarakat masih merasa kebingungan untuk melakukan proses komersialisasi karena masih minimnya pengetahuan dalam bidang pemasaran dan bisnis. Oleh karena itu, para peserta pelatihan berharap untuk melanjutkan program pelatihan ini dengan fokus utama terkait dengan pemasaran produk yang dihasilkan. 


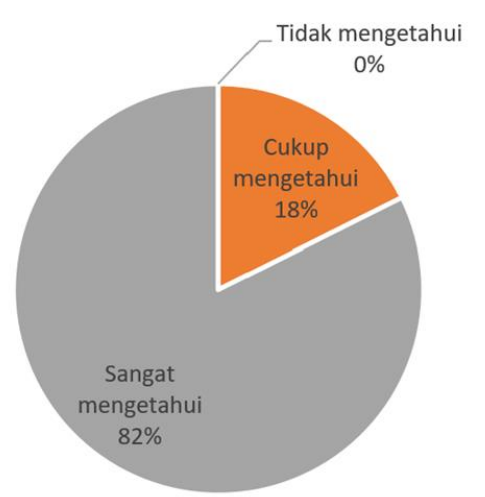

(a)

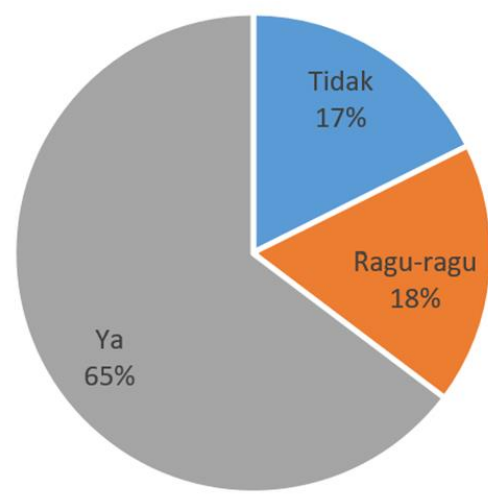

(b)

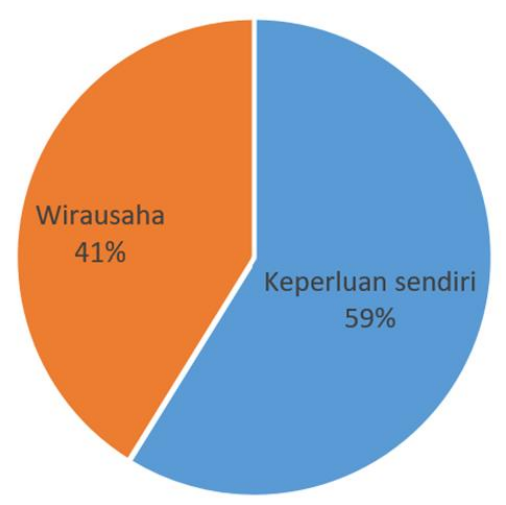

(c)

Gambar 9. Hasil post-test kegiatan pelatihan: (a) tingkat pengetahuan pemanfaatan sampah plastik sebagai bahan dasar produk kreatif; (b) keinginan untuk memanfaatkan sampah plastik sebagai produk kreatif; (c) tujuan pengembangan produk kreatif berbasis limbah plastik

\section{Kesimpulan}

Desa Penyak merupakan salah satu desa di Kepulauan Bangka Belitung yang berbatasan langsung dengan laut. Seiring dengan upaya pembentukan desa wisata di wilayah ini, maka pihak Pemerintah Desa Penyak telah berupaya untuk mengantisipasi sampah melalui pembentukan bank sampah. Namun demikian, Pemerintah Desa Penyak juga mengharapkan adanya upaya lanjutan untuk mengembangkan produk-produk kreatif berbasis limbah anorganik. Pada pelatihan ini dilakukan suatu pelatihan baik melalui pemberian materi maupun pelatihan secara langsung untuk memberikan bekal keterampilan kepada para masyarakat Desa Penyak. Berdasarkan evaluasi tampak bahwa terjadi peningkatan pengetahuan pemanfaatan sampah plastik dan mayoritas masyarakat yang mengikuti pelatihan ingin memanfaatkan sampah plastik sebagai produk kreatif. Selain itu, berdasarkan aspek tujuan pengembangan produk kreatif diperoleh informasi bahwa sudah mulai muncul beberapa masyarakat yang ingin menjadikan produk kreatif menjadi suatu produk untuk berwirausaha.

\section{Ucapan Terima Kasih}

Kegiatan pengabdian kepada masyarakat ini didanai oleh Lembaga Penelitian dan Pengabdian kepada Masyarakat (LPPM) Universitas Bangka Belitung melalui skema Pengabdian Dosen Tingkat Jurusan Tahun 2020 (PMTJ UBB 2020). 


\section{Daftar Pustaka}

Afriani, F., Widyaningrum, Y., Kurniawan, W., Aldila, H., \& Tiandho, Y. (2020). Sosialiasi teknik penyimpanan produk hasil tangkapan laut dengan metode beku di Desa Penyak. Journal of Appropriate Technology for Community Services, 1(2), 113-118.

Arico, Z., \& Jayanthi, S. (2017). Pengolahan limbah plastik menjadi produk kreatif sebagai peningkatan ekonomi masyarakat pesisir. MARTABE: Jurnal Pengabdian Masyarakat, 1(1), 16.

Chamas, A., Moon, H., Zheng, J., Qiu, Y., Tabassum, T., Jang, J., . . . Suh, S. (2020). Degradation rates of plastic in the environment. ACS Sustainable Chemistry \& Engineering, 8(9), 34943511.

Gusa, R. F., Sari, D. N., Afriani, F., Sunanda, W., \& Tiandho, Y. (2020). Effect of electrode numbers in electrocoagulation of Batik Cual wastewater: analysis on water quality and energy used. IOP Conference Series: Earth and Environmental Science, 599, 012061.

Kanti, M., Mukhirah, \& Dewi, R. (2020). Kreasi kerajinan daur ulang limbah plastik. Jurnal Ilmiah Mahasiswa Pendidikan Kesejahteraan Keluarga, 5(4), 31-44.

Nadlifatin, R. (2018). Pengolahan limbah plastik menjadi produk kerajinan tangan untuk meningkatkan ekonomi masyarakat Sendang Dajah. Jurnal Abdikarya: Jurnal Karya Pengabdian Dosen dan Mahasiswa, 1(1), 98-102.

Nasution, R. (2015). Berbagai cara penanggulangan limbah plastik. Elkawnie: Journal of Islamic Science and Technology, 1, 97-104.

Prihatmoyo, P., Dermawan, D., \& Bisono, F. (2018). Rancang bangun mesin destilator pengubah limbah plastik menjadi minyak. Proceedings Conference on Design Manufacture Engineering and its Application, 2(1), 105-110.

Putra, H. P. \& Yurindala, Y. (2010). Studi pemanfaatan sampah plastik menjadi produk dan jasa kreatif. Jurnal Sains dan Teknologi Lingkungan, 2(1), 21-31.

Sandi, Nurdandi, D., \& Tiandho, Y. (2019). Pengaruh jarak antar plat dalam penjernihan limbah batik cual dengan metode elektrokoagulasi. Prosiding Seminar Nasional Penelitian dan Pengabdian pada Masyarakat, 3(1), 12-14.

Setyawan, Y. M., Putro, G. P., Santosa, A. B., \& Fajar, M. (2020). Pemilihan mekanisme pencetak pada mesin pengolah limbah plastik menjadi paving block. IMDec, 2, 313-318.

Smith, M., Love, D., Rochman, C., \& Neff, R. (2018). Microplastics in seafood and the implications for human health. Current Environmental Health Reports, 5(3), 375-386.

Sujithira, R., \& Velmurugan, P. (2020). Microplastics in seafood-A tenet of hazard. Biotica Research Today, 2(7), 635-637. 